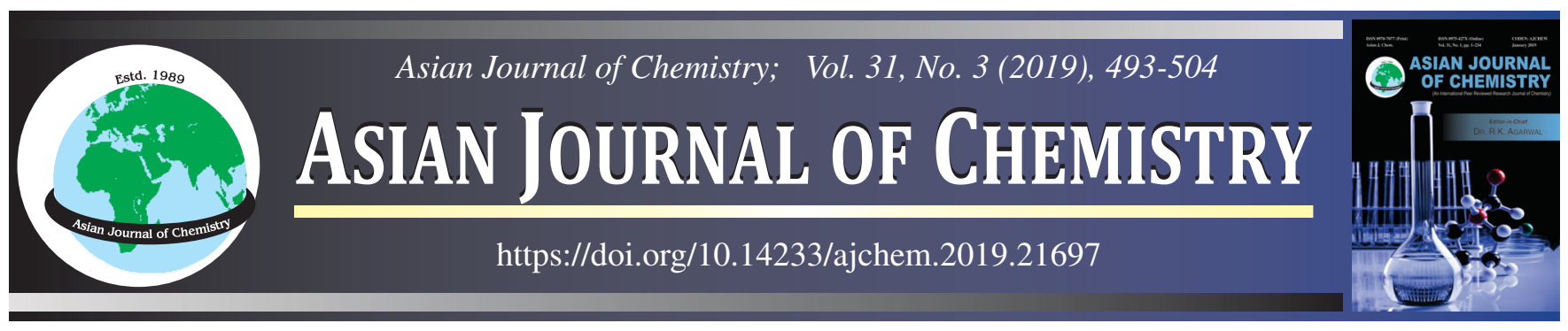

REVIEW

\title{
Schiff Base Metal Complexes as Anticancer Agents
}

\section{G. SRidevi ${ }^{1,2, *, \bullet}$, S. Arul Antony ${ }^{3}$ and R. Angayarkani ${ }^{1}$}

${ }^{1}$ Department of Chemistry. Sriram Engineering College, Chennai-602024, India

${ }^{2}$ R\&D Centre, Bharathiar University, Coimbatore-641046, India

${ }^{3} \mathrm{PG}$ and Research Department of Chemistry, Presidency College, Chennai-600005, India

*Corresponding author: E-mail: sridevi.lec@gmail.com

Received: 5 September 2018;

Accepted: 15 October 2018;

Published online: 31 January 2019;

AJC-19234

Cutting-edge practices in bioinorganic chemistry are pivotal for enhancing the layout of compounds to lessen poisonous facet effect and recognize their mechanism of action. A powerful anticancer agent should own inherent, inhibitory property and also delivery, dosage and residence time in vivo. Organic function and conformation of mutated gene may be altered by way of binding of metal ions. Upswing of activities counting on the structural data, intending in enhancing and growing different forms of metal based compounds, continuous seek of extra metal based compounds have been synthesized via revamping the prevailing chemical shape via ligand substitution. The prevailing paper addresses the trendy development in the design of novel antitumor agents primarily based on transition metal complex via highlighting the near dating among their structural alternatives and cytotoxic ability.

| Keywords: Schiff base, Mutated gene, Antitumor agents, Cytotoxic ability.

\section{INTRODUCTION}

Cancer is brought on when genetic harm to the cells prevents them from being attentive to regular tissue controls. The most cancers spreads when affected cells multiply rapidly, forming tumors of varying tiers. Special healing procedures can be used, depending on how a long way the most cancers have spread [1-4]. Within the case of most cancers, a chemotherapeutic agent is one which kills the swiftly dividing cells, accordingly slowing and stopping the cancer from spreading. The two principal sample of cancer cellular invasion, collective cellular migration and individual cellular migration with the aid of which tumor cells conquer limitations of extracellular matrix and spread into surrounding tissues. Two styles of migrating tumor cells, mesenchymal (fibroblast-like) and amoeboid are discovered in each pattern of cancer cell invasion [5]. Anticancer drugs have been grouped as chemotherapy, hormonal remedy and immunotherapy. Chemotherapy protected a number a families defined by way of each their chemical structure and mechanism of action, alkylating agents, antibiotics, antimetabolites, mitosis inhibitors and so on [6].
Metal complexes play a crucial role in drug remedy. the metallo-elements present in shred quantity performs vital function in residing device on the molecular stage [7]. Transition metals exhibits various oxidation states and might engage with a number of negatively charged molecules. This property of transition metal has unraveling the metal based drugs with promising pharmacological pertinence [8]. The invention of cisplatin, cis- $\left[\mathrm{Pt}^{\mathrm{II}}\left(\mathrm{NH}_{3}\right)_{2} \mathrm{Cl}_{2}\right]$, become a defining moment which induced the interest in platinum(II) and other metal containing complexes as ability novel anticancer drugs [9]. Emerging metal complex as drugs, however, isn't a smooth project. Deposition of metal ions inside the body can cause deleterious effects. As a consequence biodistribution and clearance of the metal complexes as well as its pharmacological specificity are to be taken into consideration. Reverent physiological responses of candidate drugs want to be validated with the aid of in vitro study with focused biomolecules and tissues in addition to in vivo investigation earlier than they input medical trials. A conceptual knowledge of how metallic complexes attain their activities is essential to their clinical achievement, in addition to the rational design of latest compounds with improved potency. Metal

This is an open access journal, and articles are distributed under the terms of the Creative Commons Attribution-NonCommercial-ShareAlike 4.0 (CC BY-NC-SA 4.0) International License which allows readers to freely read, download, copy, distribute, print, search, or link to the full texts of its articles and to use them for any other lawful non-commercial purpose as long as the original source is duly acknowledged. 
impact influences no longer best herbal tactics, which include cell division and gene expression, but also non-natural processes, inclusive of toxicity, carcinogenicity and antitumor chemistry. In chemotherapy, the important issue is killing the tumor cells, without causing too much damage to healthy cells [2-4]. Metal complexes formed with other metals like copper, gold, gallium, germanium, tin, ruthenium and iridium showed significant antitumor activity. In this review, we highlighted the current progress based on the interface between molecular biology and bioinorganic chemistry the design of coordination complexes for cancer treatment.

Cause of cancer: The reasons of most cancers are numerous, complex and handiest in part understood. Many elements together with environmental (vitamins/weight loss program, tobacco use, sure infections, publicity to radiation, lack of bodily activity, obesity and pollution) and inner/genetic components (inner factors inclusive of inherited mutations/differences, hormones, and immune situations), play an important position to boom the threat of most cancers. The contribution of genetic elements and environmental factors closer to most cancers hazard is round 5-10\% and 90-95\%, respectively. At some stage in metabolic process in human body oxygen-centered free radicals and different sensitive oxygen species may additionally yield as by-product by way of numerous physiological and biochemical adjustments. Overproduction of such free radicals can reason of oxidative harm to biomolecules (e.g. proteins, lipids, DNA), in the long run leading to several chronic diseases, consisting of atherosclerosis, cancer, diabetes, growing older and other degenerative sicknesses in humans.

Mechanism of anticancer drugs: The central dogma of molecular biology is deoxyribose nucleic acid (DNA) to ribonucleic acid (RNA) to protein synthesis. DNA, a genetic material of cell acts as the selective template for the production of precise varieties of transfer, ribosomal and messenger ribonucleic acid (RNA). DNA, in directing the formation of particular sequences of messenger RNA, determines which proteins can be synthesized at the RNA templates. The enzymes in flip are responsible for the shape, metabolic interest, proliferative charge and function of the cellular. Interference with the shape of DNA (alkylating agents, procarbazine) or its feature disorganizes and disrupts the cell. Compounds with this mechanism of movement had been useful anticancer drugs.

A new lanthanide Schiff base ligand, $\mathrm{N}^{2}, \mathrm{~N}^{3}-b i s$ (anthracen9-ylmethylene)pyridine-2,3-diamine (SBL) (Fig. 1) is synthesized via condensation of 2,6-diaminopyridine and anthracene9-carbaldehyde using a 1:2 ratio. ${ }^{1} \mathrm{H}$ NMR spectra confirmed the non-involvement aromatic carboxylic proton in SBL. A unique series of lanthanide (i.e., praseodymium, erbium and ytterbium)-based totally SBL steel complexes become efficiently synthesized and their usefulness had been elaborately established using UV-visible, FT-IR and fluorescence spectroscopy analyses. The synthesized SBL-based metal complexes were elaborately carried out for cytotoxicity activity as opposed to vero, human breast cancer (MCF7), and cervical (hela) anticancer cell traces. SBLPR and SBLER effectively brought on apoptosis in vero MCF7 and Hela cells in a dosage based manner. the SBLPR tested vero cells displayed a terrific biocompatibility in comparison to the complicated SBLER. The morphological

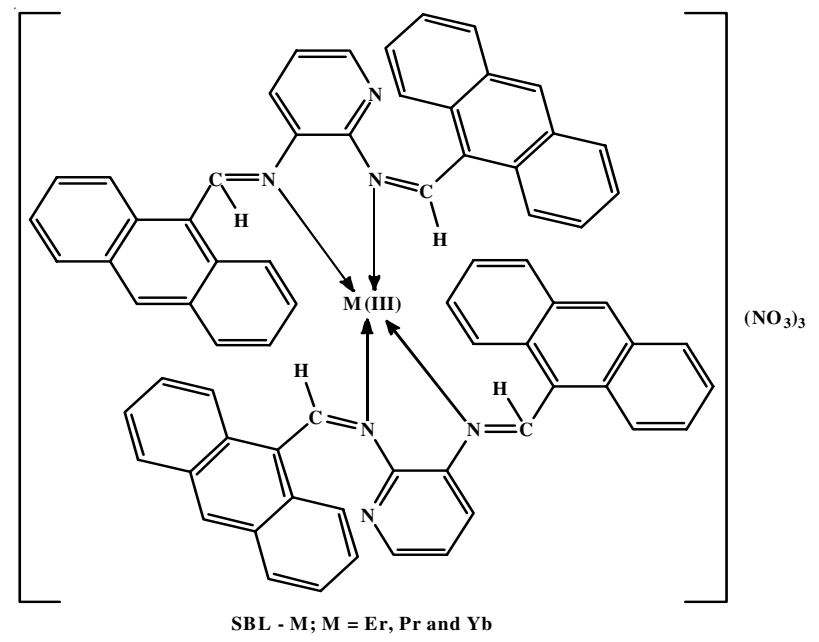

Fig. 1. Structure of lanthanide Schiff base complex

shots showed the poisonous effect of SBLPR and SBLER pattern in opposition to vero cells compared with control cells [10].

Schiff base ligands prepared from $o$-vanillin, $(R)-(+)-2-$ amino-3-phenyl-1-propanol and 2-amino-2-ethyl-1,3-propanediol. These ligands were treated with $\mathrm{Zn}$ metal to form $\mathrm{Zn}$ complexes (Fig. 2) and characterized. The in vitro cytotoxicity of metal complexes towards four kinds of cancerous cell lines (A549, HeLa, HL-60 and K562) were assayed by MTT method. Investigations on the chirality and nuclearity of zinc complexes showed that they play an important role in cytotoxic activity [11].

Sheikh et al. [12] synthesized new type of tetradentate nitrogen donor (N4) Schiff base ligand (Fig. 3). The ligands prepared were reacted with $\mathrm{Cu}(\mathrm{II}), \mathrm{Ni}$ (II) and $\mathrm{Co}(\mathrm{II})$. All the metal compounds synthesized were tested for cytotoxic activity by MTT assay on $\mathrm{H} 9 \mathrm{C} 2$ cardiac mycoblast. The results showed that $\mathrm{Ni}(\mathrm{II})$ complex was very active and less cytotoxic among all the metal chelates screened [12].

New Schiff base ligand with molecular formula $\left(\mathrm{C}_{20} \mathrm{H}_{23} \mathrm{NO}_{3}\right)$, has been prepared and treated with copper metal [13]. The copper metal complex was screened for spectroscopic analyses. The in vitro cytotoxicity of copper metal complex were tested by MTT assay on different cancer cell line. Investigated results showed that copper complex (Fig. 4) show positive synergic effect and high selective in dose dependent manner [13].

Another new copper(II) complex (Fig. 5) was synthesized and its antiproliferative effect on HT-29 colon cancer cells were investigated [14]. The copper complex has a potent antiproliferative effect with $\mathrm{IC}_{50}$ value of $2.87 \mu \mathrm{g} / \mathrm{mL}$. Moreover, the copper complex when treated with HT-29 cells underwent apoptosis death and showed a elevation in cell population and also at a concentration of $6.25 \mu \mathrm{g} / \mathrm{mL}$, the complex shows more elevation. All these results implied that the copper(II) complex possesses potential ability for future in vivo and as cancer cell line to develop chemotherapeutic agents [14].

Pyridine based cobalt metal complex were synthesized and characterized by Xiao et al. [15]. The pyridine-metal complex (Fig. 6) were screened for in vitro cytotoxic studies in which three human skin cancer cell lines (A-431, HT-144 and SK-MEL-30) were used. The antiproliferative effect of test compounds in opposition to each of tumor cell lines can 


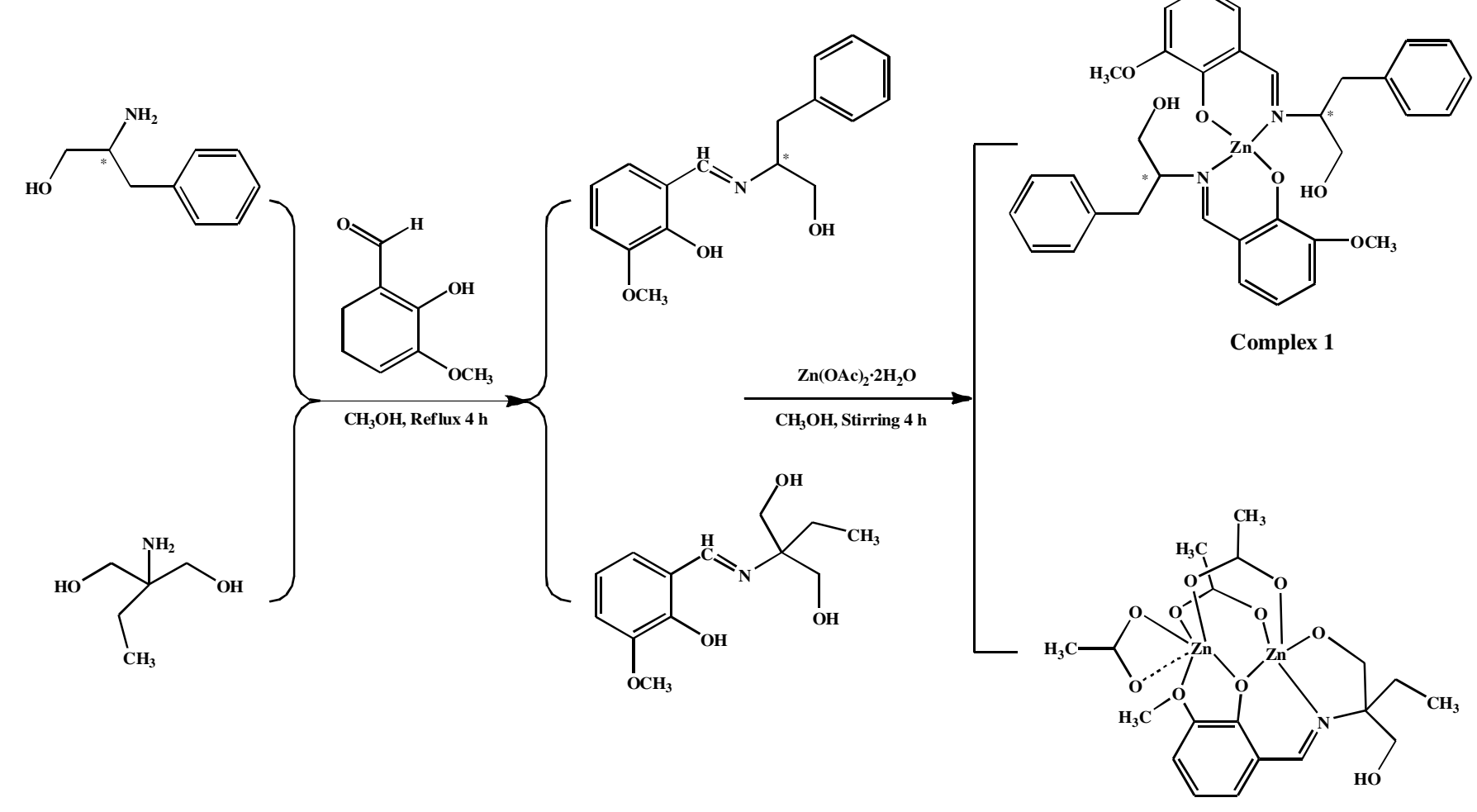

Complex 2

Fig. 2. Zn complex from $o$-vanillin and $(R)-(+)-2-$ amino-3-phenyl-1-propanol

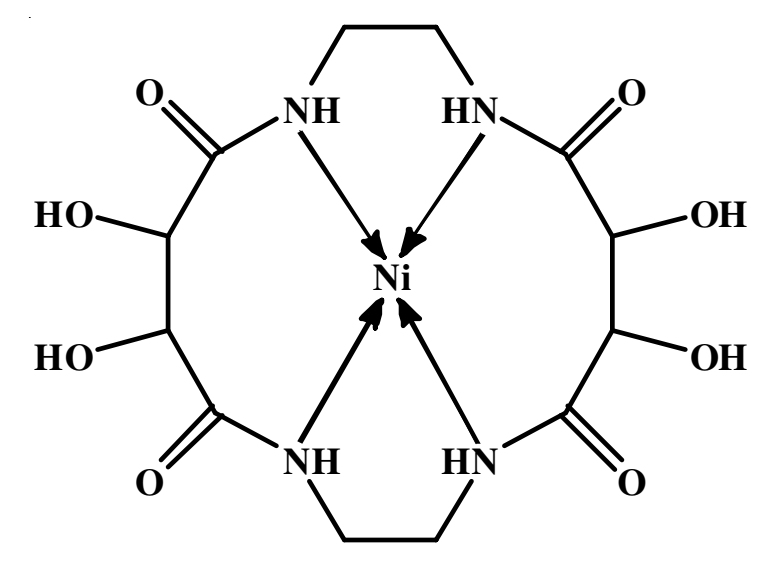

Fig. 3. Structure of macrocyclic tetradendate nickel complex

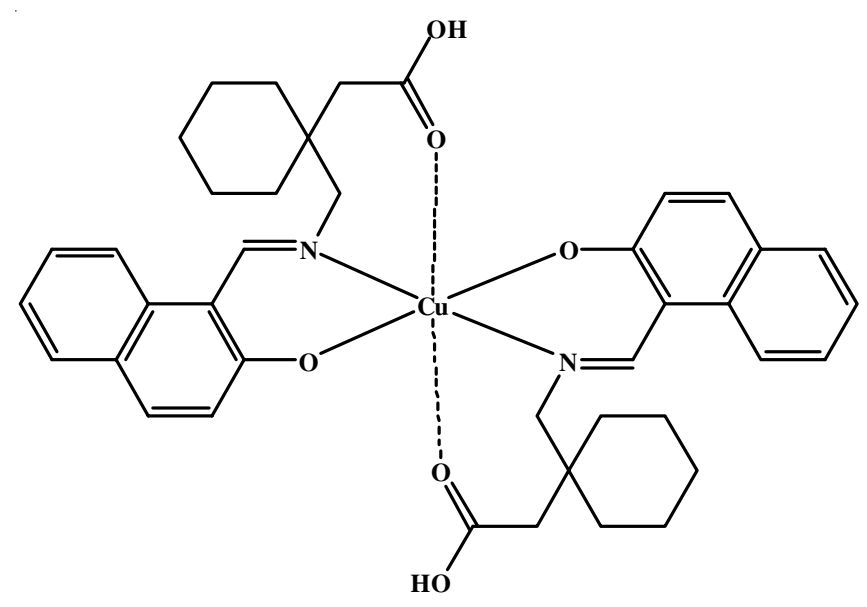

Fig. 4. Structure of copper complex with imine moiety

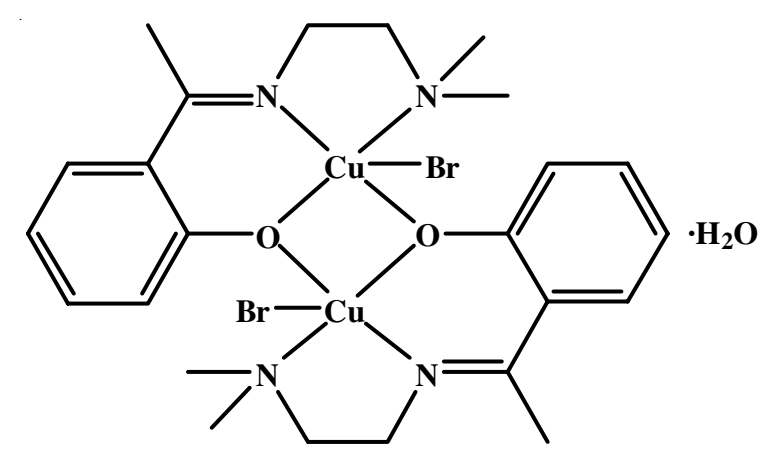

Fig. 5. Structure of $\mathrm{Cu}(\mathrm{BrHAP})_{2}$ Schiff base

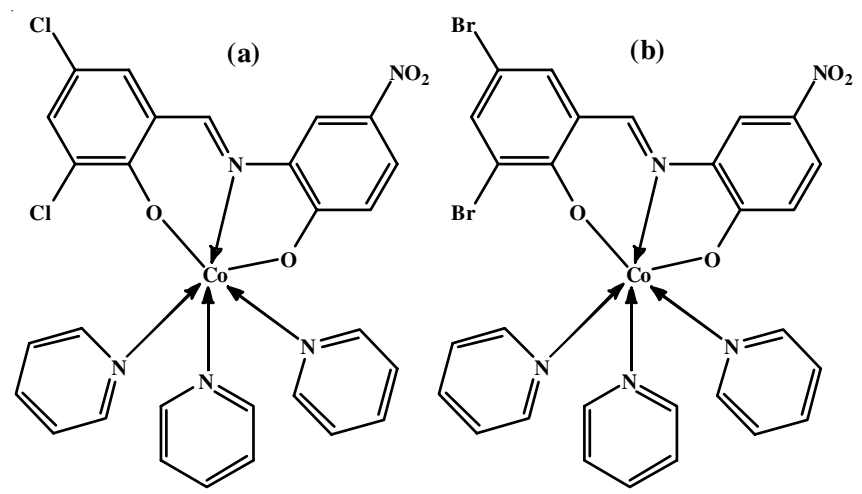

Fig. 6. Structure of metal complexes of $\mathrm{Py}_{3} \mathrm{CoL}_{1}$ (a) and $\mathrm{Py}_{3} \mathrm{CoL}_{2}$ (b)

be arranged in a lowering order in keeping with the measured concentration required to inhibit tumor cell proliferation by $50 \%\left(\mathrm{IC}_{50} \mu \mathrm{M}\right)$. The results confirmed that the compounds exhibited widespread growth inhibition interest at three tumor 
cell lines in comparison to their corresponding organic ligand [15].

$\mathrm{Co}(\mathrm{II}), \mathrm{Ni}$ (II), $\mathrm{Cu}$ (II) and $\mathrm{Zn}$ (II) complexes (Fig. 7) derived from vanillin and acetoacetanilide with ethylenediamine were synthesized as repored by Kumar and Varma [16]. The ligand and its metal complexes were tested for cytotoxic activities and found that copper complexes have higher inhibitory concentration $\left(\mathrm{IC}_{50}\right)$ value around $49 \mu \mathrm{g} / \mathrm{mL}$. DLA cell induced solid tumor model and EAC cell induced ascites tumor model were mainly used for antitumor studies. Copper complexes were administrated at different concentrations in Swiss albino mice to access increases in the survival rate and the life span of ascites tumor enduring mice in a dose dependent manner [16].

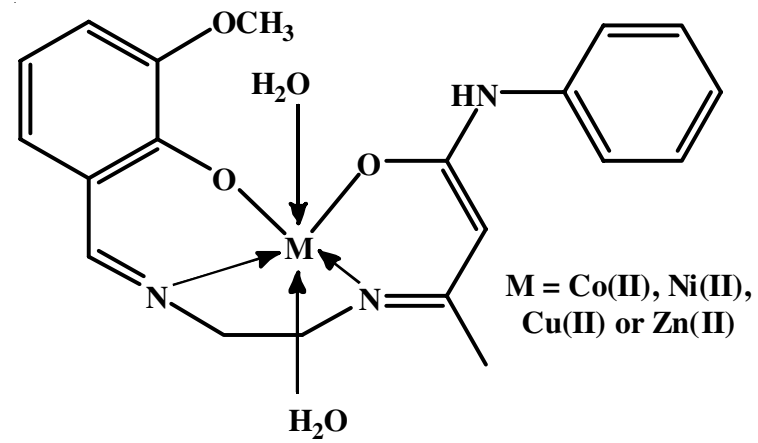

Fig. 7. Structure of metal complexes derived from vanillin and ethylenediamine

Tin(IV) complexes (Fig. 8) have been synthesized from $\mathrm{N}^{\prime}$-[(1E)-(2-hydroxy-3-methoxyphenyl)methylidene]pyridine4-carbohydrazone [17]. The five human tumor cells lines (HL60, A549, HT-29, HCT-116 and Caco-2) were screened for in vitro cytotoxicity by MTT assay. These complexes show better antiproliferative outcomes in cultured cancerous cells and their cytotoxic activity correlates with intracellular organo tin(IV) concentration. Studies revealed that the diphenyl tin compounds have less cytotoxicity interaction than tin(IV) complex [17].

The novel synthesis of disubstituted hexahydroquinolines substituted with benzensulfonyl and phenylthiocarbamoyl pharmacophores (Fig. 9) that are known to contribute to chemotherapeutic effects is described [18]. The six synthesized compounds were able to show remarkable cytotoxic efficiency against human<smiles>[R]c1c2c(n(C(=S)Nc3ccccc3)c(=O)c1C#N)CCCC2</smiles>

Fig. 9. Structure of quinoline based Schiff base ligand

colon carcinoma HT29, breast adenocarcinoma MCF7 cell lines and hepatocellular carcinoma Hep-G2. Overall, the study of the results revealed that compounds could be considered as effective in both antimicrobial-anticancer agents [18].

A major challenge in cancer drug discovery was selective cytotoxic effect towards tumour cells but not the normal cells. The HTT (Fig. 10) compounds were synthesized and their antitumour activity was evaluated. The derived compounds were investigated against K562 leukemia cells and MCF-7 normal cells. The compounds showed significant antitumour against Leukemia K562 cells. With reference to cytotoxicity in normal cells, compounds showed no cytotoxic effect within $200 \mu \mathrm{m}$ but compounds showed non-selective cytotoxic effect [19].

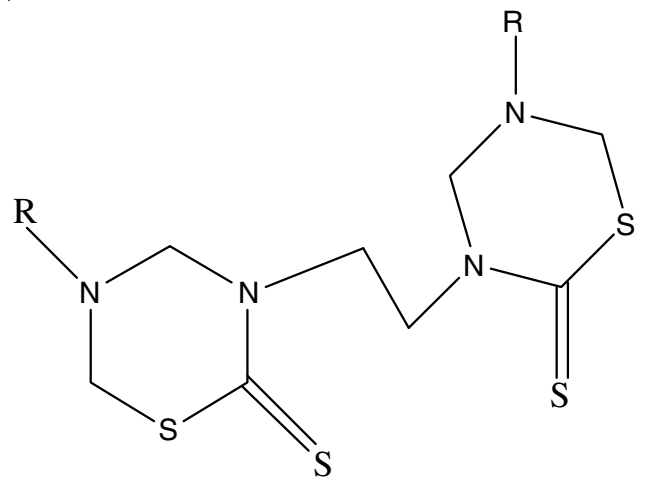

Fig. 10. Structure of HHT Ligand

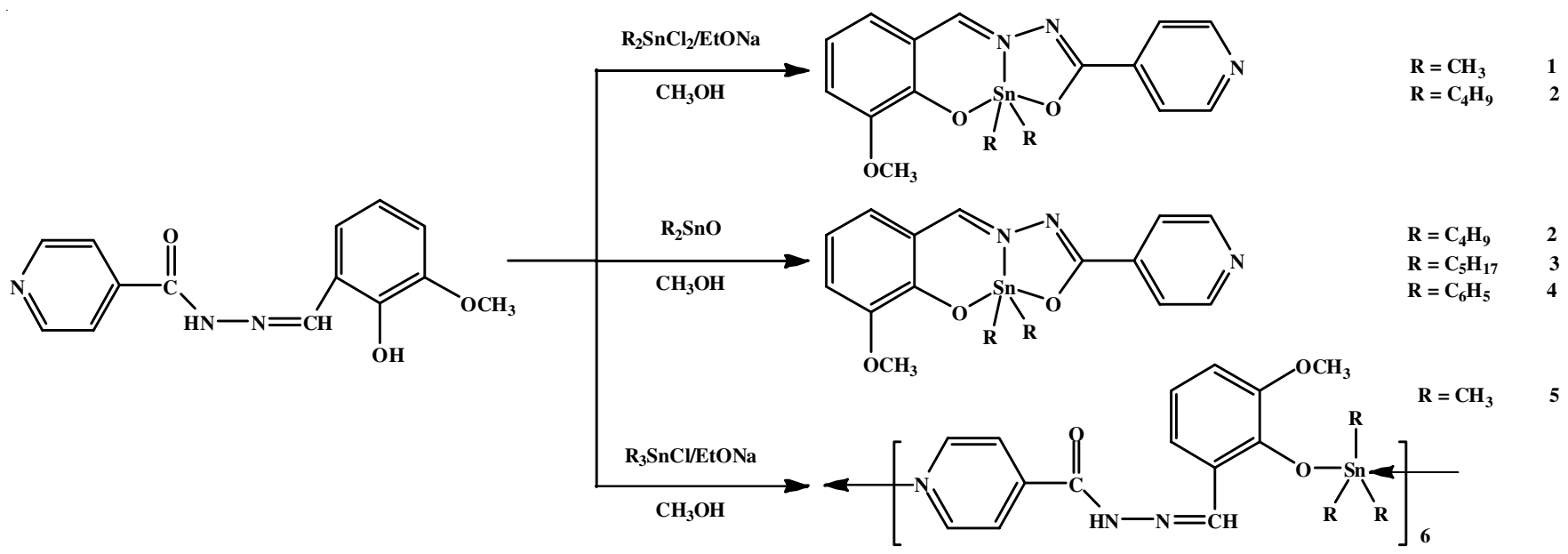

Fig. 8. Structure of tin complexes from pyridine 
The $\mathrm{Cu}(\mathrm{II}), \mathrm{Mn}(\mathrm{II}), \mathrm{Ni}(\mathrm{II})$,), Zn(II) and $\mathrm{Ag}(\mathrm{I})$ metal complexes with oxaloamide ligand are effective in therapeuticas well as diagnostic agents. Specific examples involving the design of metal complexes (Fig. 11) as antitumor agents are discussed. The screening of cytotoxiy of metal complex with $\mathrm{IC}_{50}$ value has been carried out. Copper(II) complexes show increased activity in comparison to the parent ligand or standard drug. Copper is used in various human cancer cell line and it is a co factor which is essential for tumour angiogenesis process. The targeted tumour cell are treated with copper binding ligand, where copper can acts as a better selective cancer drugs [20].

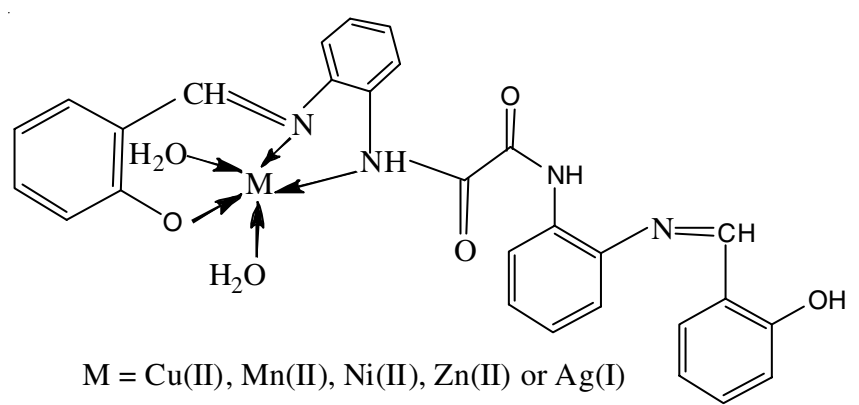

Fig. 11. Structure of metal complexes of oxaloamide ligand

Transition metals like $\mathrm{Cr}$ (III), $\mathrm{Ni}$ (II), $\mathrm{Cu}$ (II), $\mathrm{Ru}$ (III), $\mathrm{Mn}$ (II) and $\mathrm{Zn}$ (II) ions were prepared from heterocyclic furan based Schiff compounds (Fig. 12). The metal complexes were evaluated against human breast (MCF-7) and lung cancer (A549) cell lines. The cytotoxic activities of all compounds were better towards human breast (MCF-7) and lung cancer (A549) cell lines [21].

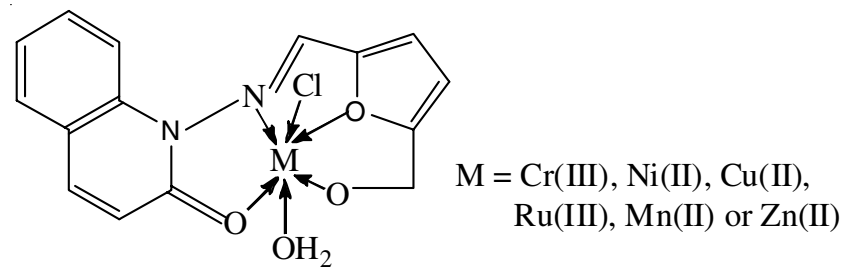

Fig. 12. Structure of metal complexes derived from Schiff base containing heterocyclic furan moiety

Schiff bases derived from 4-aminoantipyrine (Fig. 13) were investigated for the effect of nitro group on its antibacterial activity, antitumor study of effects of electron withdrawing and donating group on antioxidant potential. The compounds were synthesized with less time using green method. These compounds show significant cytotoxic activity results due to the presence of $\mathrm{NO}_{2}$ group [22].<smiles>[R]C([R])=Nc1cn([TlH])n(-c2ccccc2)c1=O</smiles>

Fig. 13. Structure of 4-amino antipyrine derived ligand
$\mathrm{Cu}(\mathrm{II}), \mathrm{Ni}(\mathrm{II})$ and $\mathrm{Zn}(\mathrm{II})$ complexes with Schiff base, 2((E)-(5-methylisoxazol-3-ylimino)methyl)-4-methoxyphenol (MIIMMP) (Fig. 14) were prepared in an ethanolic medium [23]. Based on spectral data and molecular modeling data, $\mathrm{Ni}(\mathrm{II})$ and $\mathrm{Zn}$ (II) metal complexes have octahedral geometry, whereas $\mathrm{Cu}$ (II) complex has tetragonal geometry. The antimicrobial activity and cytotoxic activities of ligand and its metal complexes were studied on bacteria, fungi and human cervical carcinoma cells (HeLa). Metal complexes provide good results against cytotoxicity.

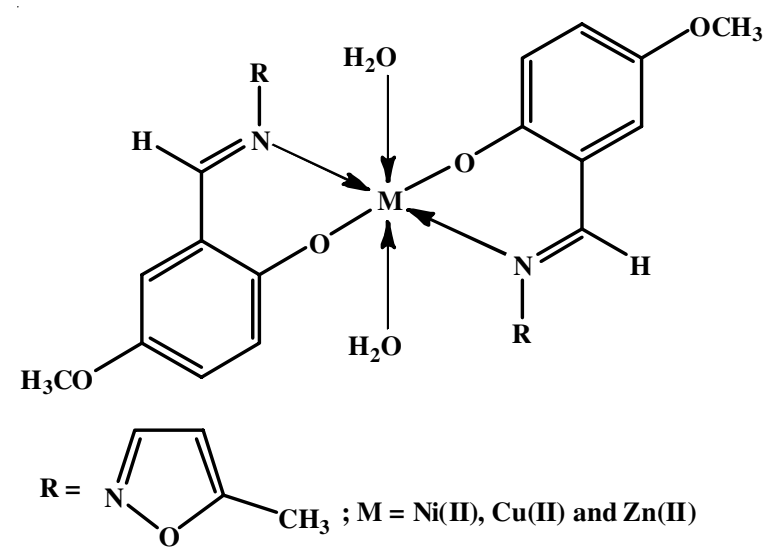

Fig. 14. Structure of 2-((E)-(5-methylisoxazol-3-ylimino)methyl)-4methoxyphenol (MIIMMP)

Schiff base transition metal complexes (Fig. 15) were synthesized by the condensation of isonicotinohydrazide with 1-phenyl indoline-2,3-dione [24]. The DNA cleavage and in vitro cytotoxicity of metal complex were performed by agarose gel electrophoresis method and MTT assay. The results showed that $\mathrm{Ni}(\mathrm{II})$ and $\mathrm{Cu}$ (II) complexes show better cytotoxic activity on AGS-human gastric cell line than ligand [24].

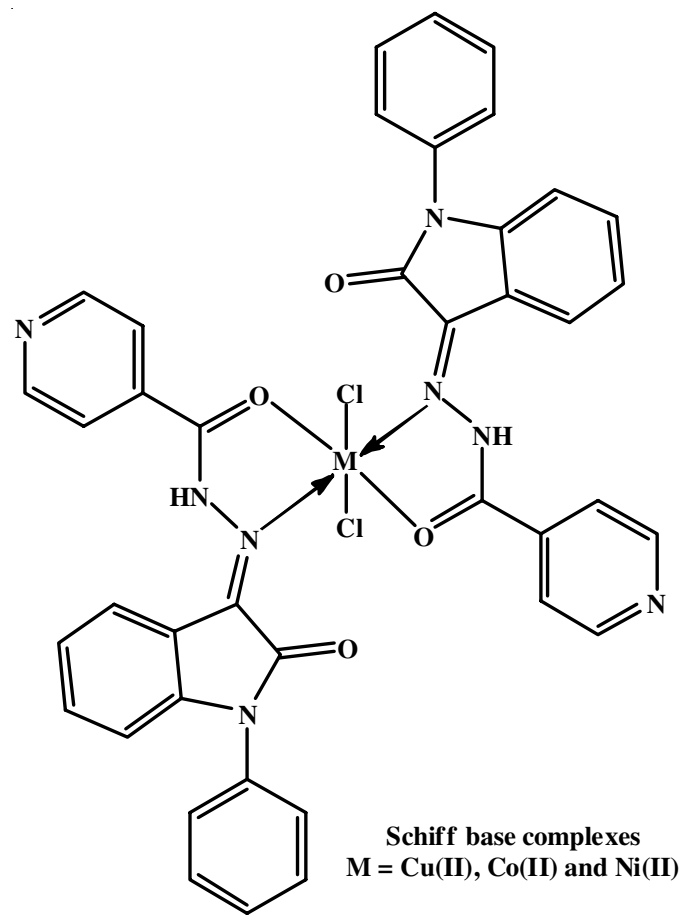

Fig. 15. Schiff base transition metal complexes derived from isonicotinohydrazide and 1-phenyl indoline-2,3-dione 
Several heterocyclic Schiff base copper complexes were designed and characterized (Fig. 16). The ligands and the metal complexes were tested against antibacterial and antifungal species by paper disc method. The ligand and metal complexes were also screened for antitumour activity against the human cervical carcinoma cancer cell line (Hela). The studies showed that few copper complexes exhibit good antitumour activity on Hela cell line [25].

Platinum(II) Schiff base ligand that derived from 5-chlorosalicylaldehyde and $o$-phenylenediamine was synthesized and charcterized (Fig. 17) [26]. The in vitro cytotoxicities of metal chelates had been investigated through microculture tetrozolium (MTT) assay against seven human tumor cell lines. Cell cycle evaluation indicated that the complex prompted apoptosis and G1-phase arrest in A549 cells. The outcome confirmed that the complex could suppress the proliferation and viability of a549 cells by colony formation assay [26].
Palladium(II) bis-chelates compounds had been synthesized and characterized through elemental analysis and spectroscopic techniques (Fig. 18) [27]. The structure of ligand and metal complex has been determined by single crystal X-ray diffraction studies. The in vitro cytotoxic action of complexes indicate that the palladium(II) complexes exhibited better antiproliferative interest than their free ligands towards different types of human cancer cell lines. Among all the studied palladium complexes, the newly synthesized palladium complex exhibited more antitumor activity on the DU145 prostate carcinoma and K562 chronic myelogenous leukemia cells, with low values of the inhibitory concentration [27].

Various heterocyclic nuclei (pyridine, $N$-methyl-pyrrole or imidazole) at C-2 are introduced in heterocyclic benzimidazole derivatives bearing amidino substituents at $\mathrm{C}-5$ of benzimidazole ring (Fig. 19) and evaluated for their antitumor and antiviral activities. The substituent having imidazolinylamidino

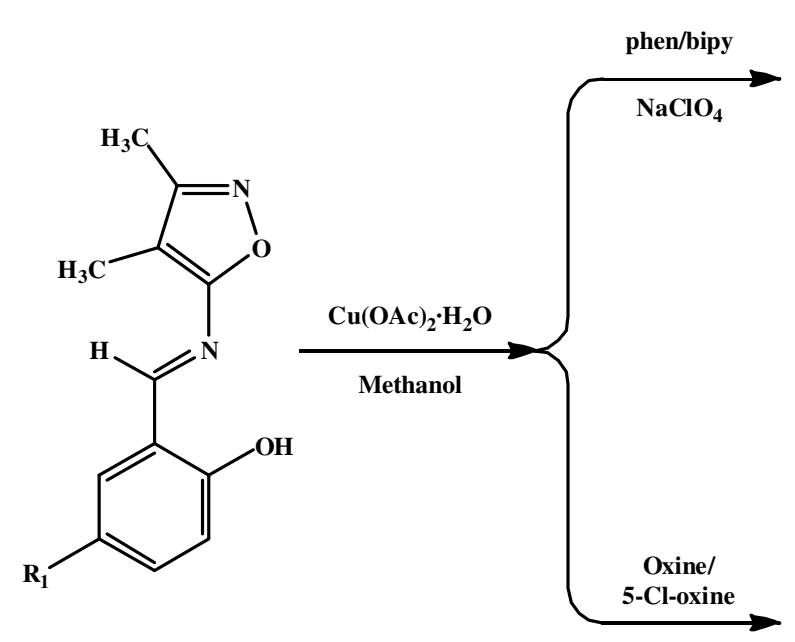<smiles>Cc1noc(C)c1C</smiles><smiles>c1ccc(-c2ccccn2)nc1</smiles>

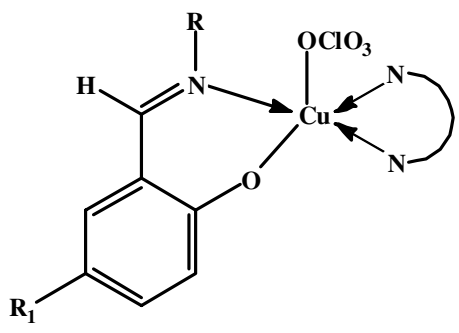

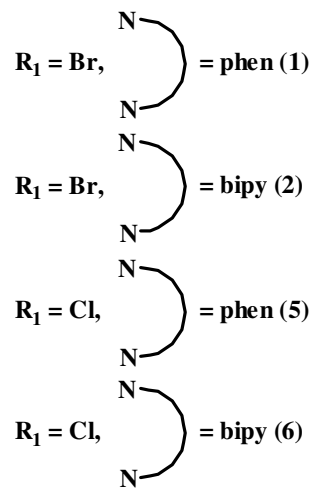

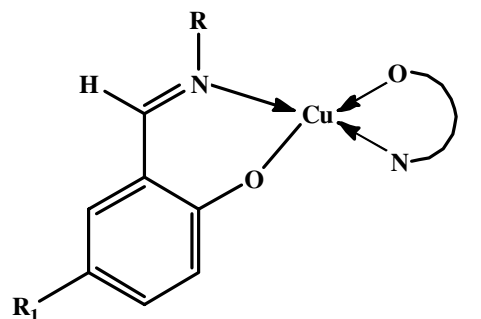

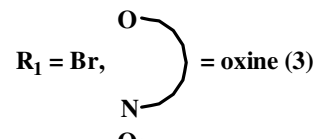<smiles>CC#CC(CO)C[18O]</smiles><smiles>[11B]=C[131I]=C(CN)CO</smiles><smiles>Oc1ccc(Cl)c2cccnc12</smiles><smiles>CC#CC(CO)CNC=[18O]</smiles>

Fig. 16. Structure of copper complexes of DMIIMBP

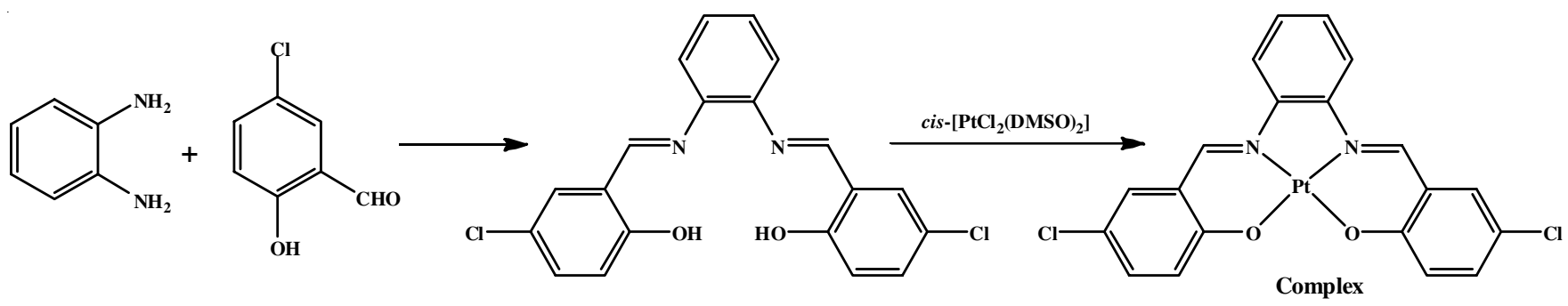

Fig. 17. Synthesis of platinum Schiff base complex 
<smiles>CC(C)=NNC(=S)Nc1ccccc1</smiles>

or<smiles>[X]c1ccccc1/C=N/NC(=S)Nc1ccccc1</smiles>

$\mathbf{X}=\mathbf{C l}, \mathbf{O H}$<smiles></smiles>

(6) $\left[\operatorname{Pd}\left(\operatorname{TSC}^{1}\right)_{2}\right]$<smiles></smiles>

(7) $\left[\mathrm{Pd}\left(\mathrm{TSC}^{2}\right)_{2}\right]\left(\mathrm{X}=2^{\prime}-\mathrm{Cl}\right)$

(8) $\left[\mathbf{P d}\left(\mathrm{TSC}^{3}\right)_{2}\right]\left(\mathrm{X}=\mathbf{3}^{\prime}-\mathrm{OH}\right)$<smiles>S=C(N/N=C\c1cccc2ccccc12)Nc1ccccc1</smiles>

$\mathrm{K}_{2} \mathrm{PdCl}_{4}$

\section{Ethanol} reflux, $2 \mathrm{~h}$

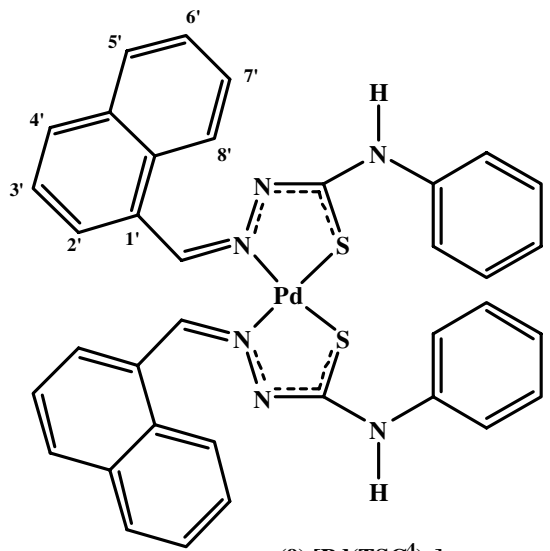

$\operatorname{Pd}(\mathbf{a c a c})_{2}$

Dichloromethane-ethanol

$\mathrm{CH}_{3} \mathrm{COONa}$,

reflux, $3 \mathrm{~h}$<smiles>O=[N+]([O-])c1c(/C=N/N2N=C(Nc3ccccc3)S[P+]23NN=C(Nc2ccccc2)S3)ccc2ccccc12</smiles>

(10) $\left[\operatorname{Pd}\left(\operatorname{TSC}^{5}\right)_{2}\right]$

Fig. 18. Synthesis of palladium Schiff base complex 


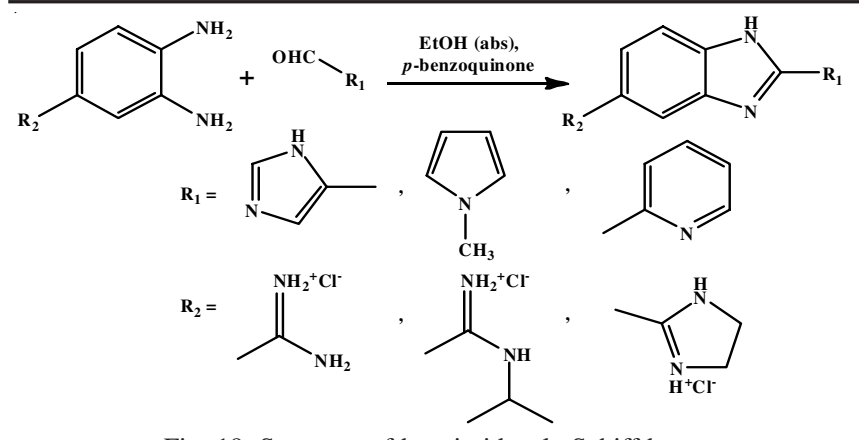

Fig. 19. Structure of benzimidazole Schiff base

produced most pronounced antiproliferative activity. Stimulately, all compounds show distinguishable selectivity toward breast cancer cell line MCF-7 [28].

Novel 2-oxoquinoline-3-carbaldehyde Schiff base ligands and their $\mathrm{Cu}(\mathrm{II})$ complexes were synthesized and analyzed (Fig. 20) [29]. The prepared ligands and their $\mathrm{Cu}$ (II) complexes were explored for their potential anticancer activity by MTT assays indicated that $\mathrm{Cu}$ (II) complexes exhibited more effective cytotoxic activity against HL60 cells, HeLa cells and potential DNA binding efficiency compared to the corresponding ligands. Complexes show more cytotoxic activity than the ligand [29].

Using an absorption titration technique, copper Schiff base complex (Fig. 21) with a distorted tetrahedral geometry has been discovered to reveal interplay through intercalation with CT-DNA [30]. The cytotoxic impact of complex analyzed on carcinocell lines (human cervical cancer cell line (HeLa), human laryngeal epithelial carcinoma cell line (Hep-2) and human breast cancer cell line (MCF-7)) demonstrated that the complex displayed extensive anticancer activity. The $\mathrm{IC}_{50}$ values of $\mathrm{Cu}$ complex were 3.04, 19.25 and $4.34 \mu \mathrm{M}$, for HeLa, Hep2 and MCF-7 cancer cell lines. In comparison to cisplatin, the $\mathrm{Cu}$ (II) complex displayed three times higher inhibitory activity against HeLa and MCF-7 [30].

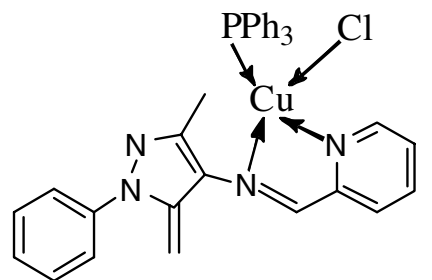

Fig. 21. Structure of heterocyclic copper Schiff base

By the condensation of salicyaldehyde with 2-amino-4phenyl-5-methyl thiazole, a ligand was prepared and forms complexes with $\mathrm{Co}(\mathrm{II}), \mathrm{Ni}$ (II), $\mathrm{Cu}$ (II) and $\mathrm{Zn}$ (II) (Fig. 22) [31]. The human tumor cell lines: breast cancer MCF-7, liver cancer HepG2, lung carcinoma A549 and colorectal cancer HCT116 were tested with the synthesized compounds for their anticancer activity with the activity of doxorubicin as a reference drug. Evaluation on result showed that the $\mathrm{Zn}$ (II) complex showed potent inhibition against human TRK in the four cell lines in the ratio 80, 70, 61 and $64 \%$ for (HepG2, MCF7, A549, HCT116) when compared to the inhibition in the untreated cells [31].

Shafeeulla et al. [32] tested the human breast cancer MCF7, cervical cancer cell HeLa K-562 and Vero cell lines at the concentrations of $80,90,100,120,130$ and $>200 \mathrm{mg} / \mathrm{mL}$ for $48 \mathrm{~h}$ using pyridine Schiff base ligand and its metal complexes (Fig. 23). The cell growth inhibition was analyzed by the MTT assay and the results revealed that complexes and the ligand exhibited an inhibitory effect on the proliferation of HeLa, MCF-7 and Vero cell lines in a dose-dependent manner [32].

Isooxazole Schiff base with 1,10-phenanthraline were condensed and react with nickel to form metal complex (Fig. 24) [33]. The antitumor activities of the metal complex with human promyelocytic leukemia (HL60) tumor cell were investigated by MTT assay. The cytotoxic activity of the complex shows good results against human promyelocytic leukemia (HL60) [33].

Schiff base metal complexes containing thiazole based coumarin compounds were synthesized and reported by Sahin et al. [34] (Fig. 25). The antitumor activity of ligand and its Pt and Pd metal complexes are tested using MTT assay. The various cancerous cell line such as MCF-7 (human cancer cell line), LS174T (human colon carcinoma cell line), LLCAP (human prostate adeno carcinoma) were tested with ligand and metal complexes. The antiproliferative activities of metal complexes were high which was determined by $\mathrm{IC}_{50}$ value. The results showed that Pd(II) complex as higher antitumor effects [34].

Organometallic platinum complexes containing a chloride, cis-cyclooctene and a Schiff base ligand have been prepared and characterized (Fig. 26) [35]. Three aliphatic amines and four aromatic amines were chosen as representative examples. The imine functionality is trans to organic cyclooctene group. Complex which contained the longest aliphatic chain studied (octyl group), was the most promising for inducing apoptosis in the malignant MB231 breast cancer cell line. Conversely, complexes which contained aromatic groups, were the most active against renal cell carcinoma (RCC) cell lines [35].

Manikandan et al. [36] have reported the Co(II) complexes of 2-acetylpyridine $\mathrm{N}$-substituted thiosemicarbazone with $\left(\mathrm{PPh}_{3}\right)_{2}$ (Fig. 27). The higher cytotoxic activity for the complex substituted benzene may be due to the terminal phenyl substitution of coordinated ligand. By comparing the cytotoxicity with conventional standard cisplatin, it is found that the complexes exhibited excellent activity in both cancer cell lines. However,

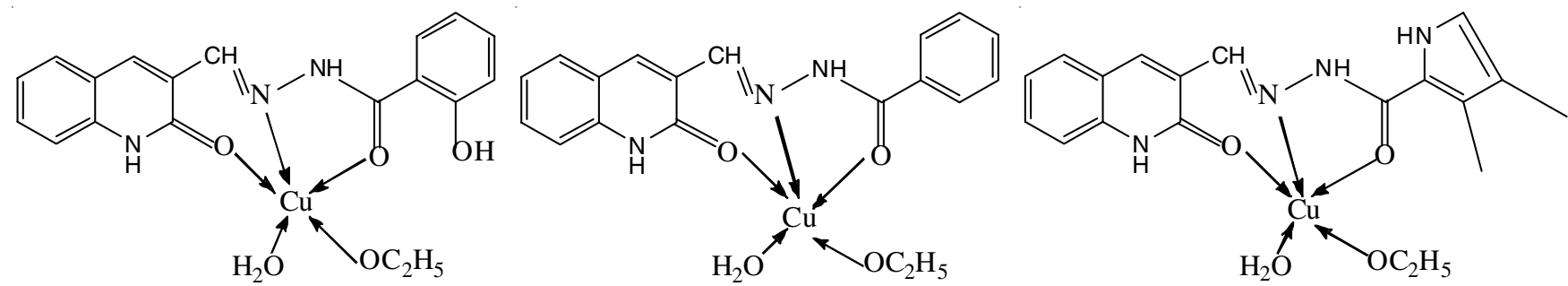

Fig. 20. Structure of copper complexes of 2-oxoquinoline-3-carbaldehyde Schiff base 

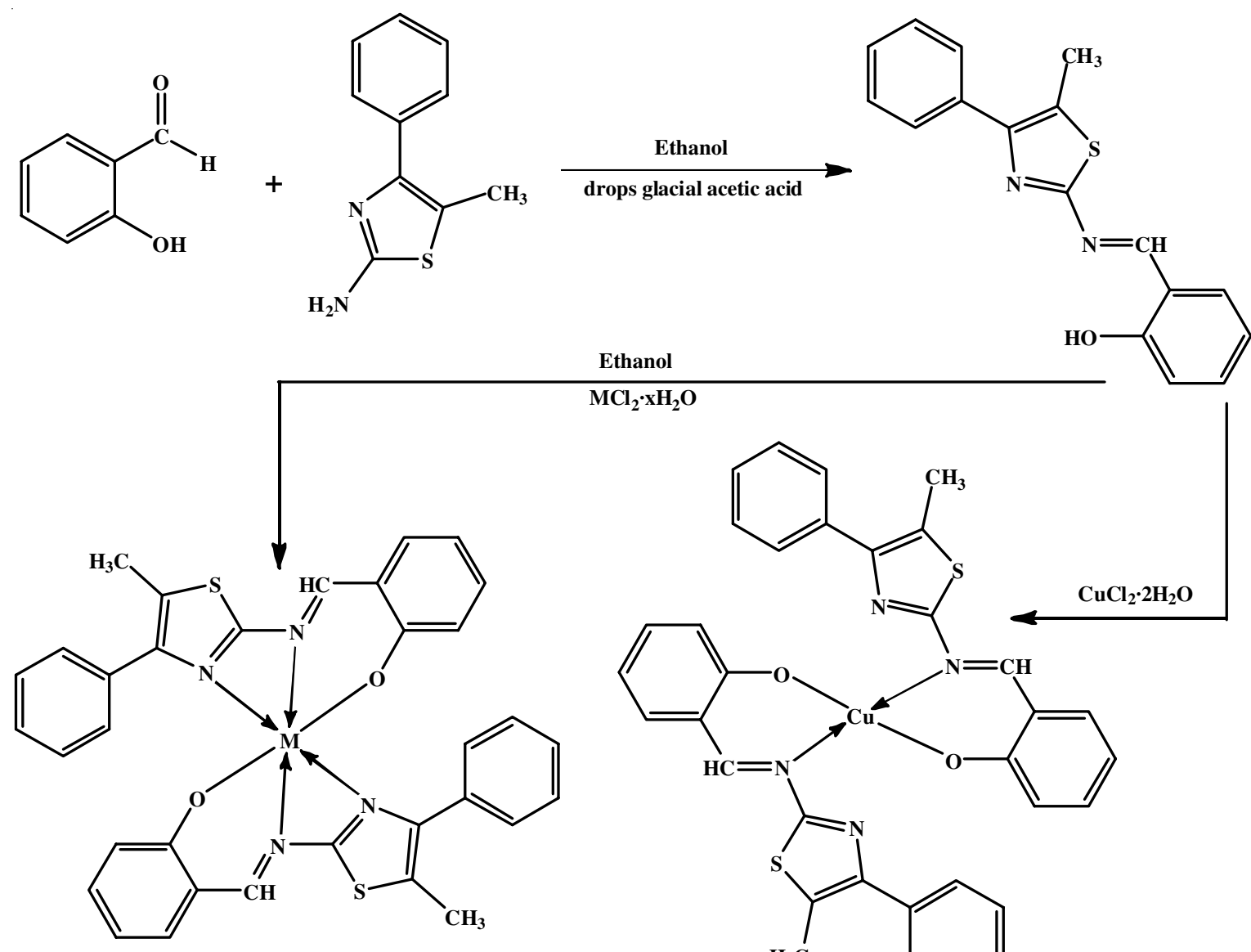

Ethanol

$\mathrm{MCl}_{2} \cdot \mathrm{xH}_{2} \mathrm{O}$

$\mathrm{M}=\mathrm{Co}(\mathrm{II}), \mathrm{Ni}(\mathrm{II}), \mathrm{Zn}(\mathrm{II})$

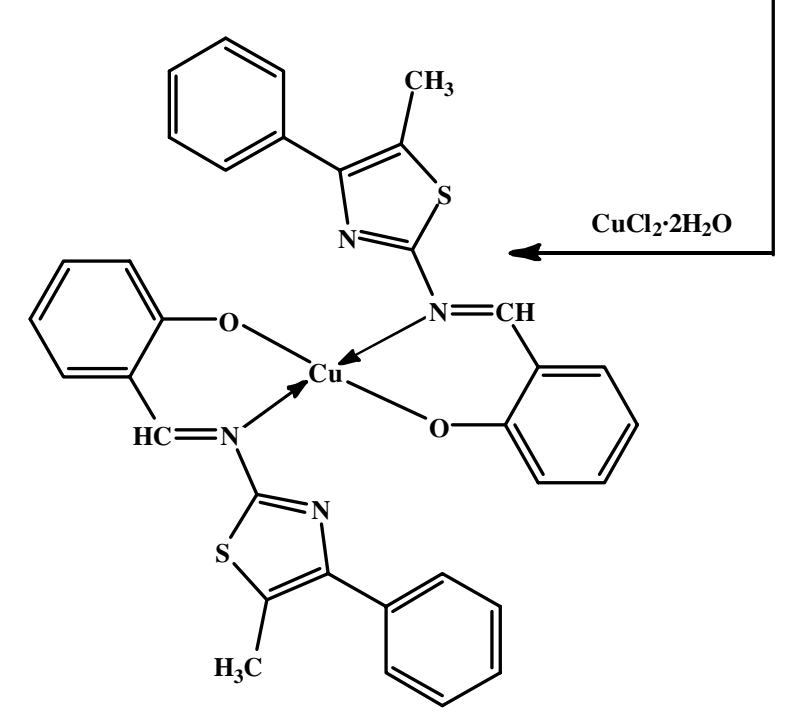

Fig. 22. Synthesis of Schiff base metal complexes containing thiazole moiety

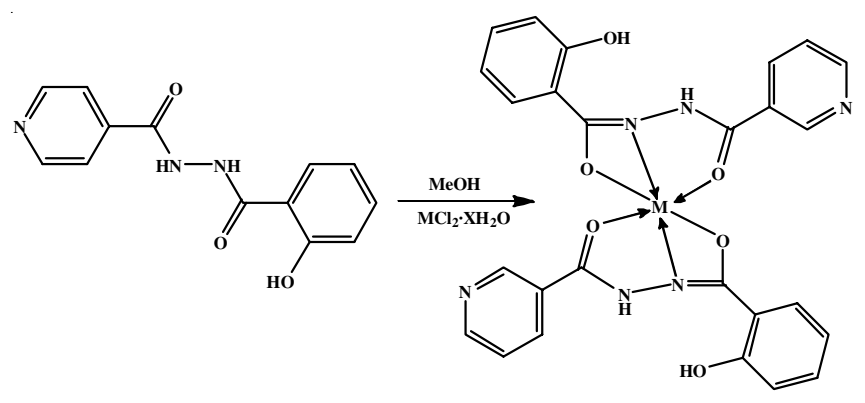

Fig. 23. Synthesis of pyridine Schiff base metal complex

the cytotoxic activity of complexes against human breast cancer cell line (MCF-7) stood higher than that of skin carcinoma cell line (A431).

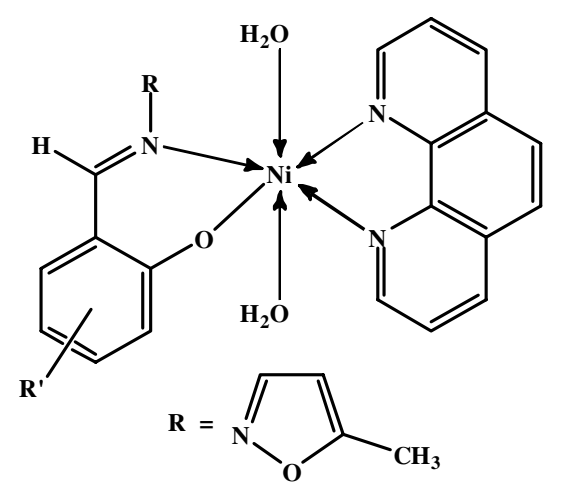

$\mathrm{R}^{\prime}=\mathrm{H}, 4-\mathrm{Cl}, 2-\mathrm{OC}_{2} \mathrm{H}_{5}, 4-\mathrm{NO}_{2}, 4-\mathrm{CH}_{3}, 4-\mathrm{Br}, 5-\mathrm{OCH}_{3}, 3-\mathrm{OH}$

Fig. 24. Structure of nickel(II) complex of isooxazole Schiff base with 1,10phenanthraline Schiff base

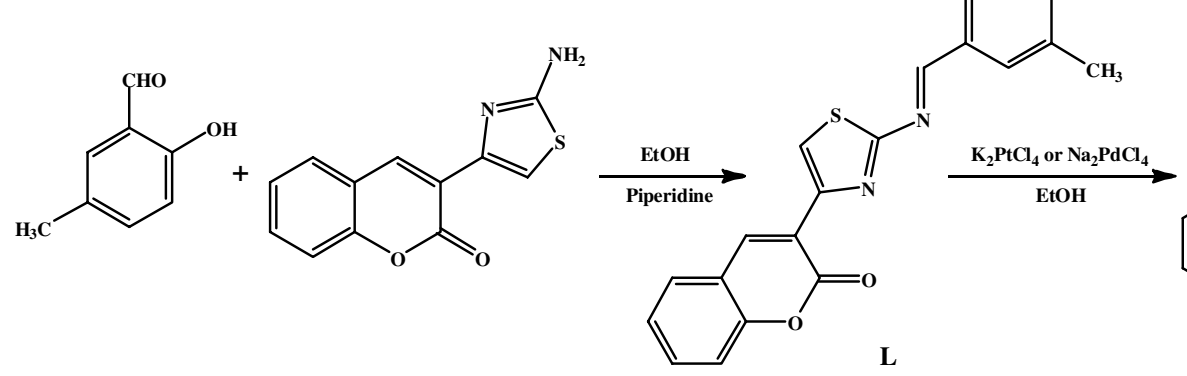

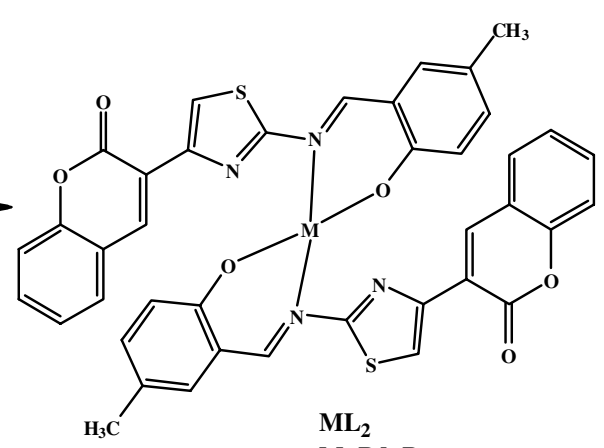

M: Pd, Pt

Fig. 25. Synthesis of coumarin thiazole Schiff base metal complexes 


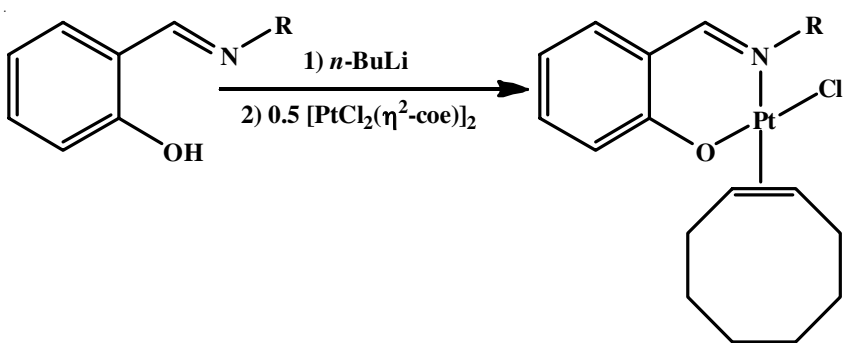

Fig. 26. Synthesis of platinum cyclooctene complexes

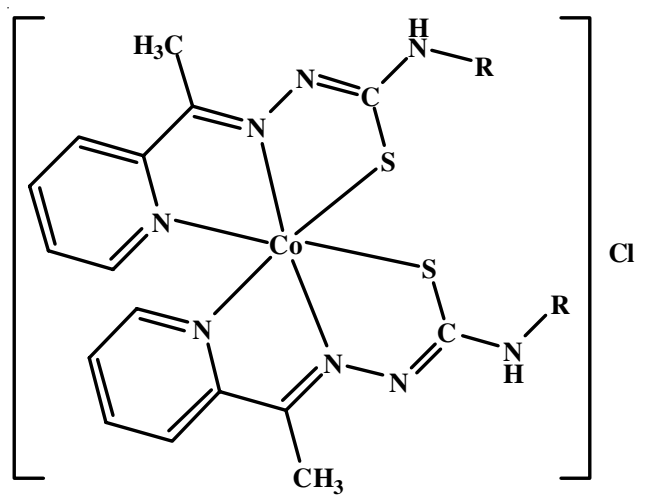

Fig. 27. Structure of 2-acetylpyridine N-substituted thiosemicarbazone Schiff base cobalt(II) complex

Zinc, silver and palladium complexes of 6-amino-4-hydroxy2-thiopyrimidine have been synthesized and characterized (Fig. 28) [37]. The free Hahtp and its complexes, [ $\left.\mathrm{Zn}(\operatorname{ahtp})_{2}\left(\mathrm{H}_{2} \mathrm{O}\right)_{2}\right]$, [Zn(Hahtp $\left.)_{2}\left(\mathrm{PPh}_{3}\right)\left(\mathrm{H}_{2} \mathrm{O}\right)\right],\left[\mathrm{Zn}\left(\right.\right.$ Hahtp)(bpy)Cl $\left.\mathrm{Cl}_{2}\right],[\mathrm{Pd}($ phen $)$ (Hahtp]Cl and $\left[\mathrm{Ag}(\mathrm{Hahtp})\left(\mathrm{PPh}_{3}\right)\left(\mathrm{H}_{2} \mathrm{O}\right)\right]$ have been tested

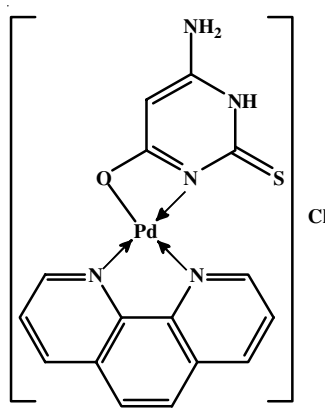

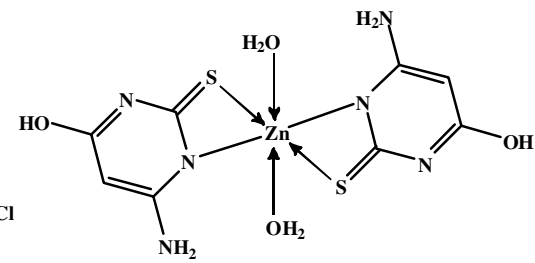<smiles></smiles>

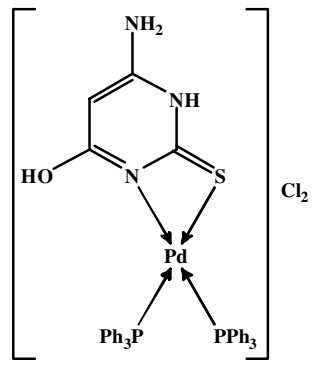

Fig. 28. Structure of Hahtp Schiff base complexes of Pd, Ag and Zn against the human breast cancer MDA-MB231 cell line. The $\left[\mathrm{Ag}(\mathrm{Hahtp})\left(\mathrm{PPh}_{3}\right)\left(\mathrm{H}_{2} \mathrm{O}\right)\right]$ complex exhibits the highest efficacy with a mean $\mathrm{IC}_{50}$ value of $4.7 \mu \mathrm{M}$.

Similarly, few metal complexes were synthesized using the ligand 5,6-diamino-4-hydroxy-2-mercaptopyrimidine (Fig. 29) [38]. There are different types of mode of chelation involved in these metal complexes. These metal complexes were also evaluated against the human serous ovarian cancer cell line (OV-90) and human ovarian cancer cell line (OVCAR-8). The metal complexes exhibit high potential cytotoxic activity [38].

El-Deen et al. [39] reported few metal (Zn, Pt, Pd) complexes when reacted with piperdine-2-carboxylic acid. The free piperdine ligand and their metal complex are tested for their in vitro cytotoxicity on serous ovarian cancer, OV 90 cell line. The metal complexes exhibit good cytotoxic activity [39].

Ruthenium compounds include ruthenium cluster, ruthenium platinum mixed compound, ruthenium DNA intercalators have the ability to form supramolecular architecture and multinuclear complex. It is very less toxic metal and has the ability to mimic iron binding serum protein which reduces the concentration of free plasma ruthenium and increases the concentration that affect the cancer cells when compared to the healthy cells. Ruthenium complexes with plasma bounding possess high affinity to tumour cells with transferring receptors [40].

Shen et al. [41] reported the synthesis and characterization of divalent transition metal complexes e.g., $\mathrm{Co}(\mathrm{II}), \mathrm{Cu}(\mathrm{II})$, $\mathrm{Cd}(\mathrm{II})$ and $\mathrm{Mn}$ (II) with nicotinohydrazide ligand. The complex also used for in vitro cell experiment to test the antitumour effect. The results revealed that the uncomplexed ligand show cytotoxic effect than the metal complexes. Metal complexes can effectively decrease the proliferation rate of different type of cancerous cell line like human gastric cancer cells, human esophageal cancer cell line (ECA109) in a dose dependent manner [41].

Schiff base copper(II) complexes containing mixed ligands salicyclic acid and benzoic acid were synthesized as reported by Lian et al. [42]. The complexes were evaluated against the cytotoxicity of cancer cell line (human cervical carcinoma Hela) and human liver hepatocellular cancer cell line HepG-2). The colorimetric cell proliferation assay and clorogenic assay showed that these complex have improved cytotoxicity. Copper complex containing salicyclic acid as a auxiliary ligand displayed a stronger anticancer activity [42].

Benzimidazole Schiff base ligand have been synthesized by the condensation of 2-hydroxy-1-napthaldehyde and 2-((1$R-1-H$-benzimidazol-2-yl)phenyl-imino)naphthol. The ligands were treated with $\mathrm{Cu}\left(\mathrm{NO}_{3}\right)_{2}$ to give copper(II) metal complexes. The complexes showed in vitro cytotoxic effect against human<smiles>CC1=C(C)N(C)N(S(=O)(=O)C=CN(C)C)C(O)=C1N</smiles>

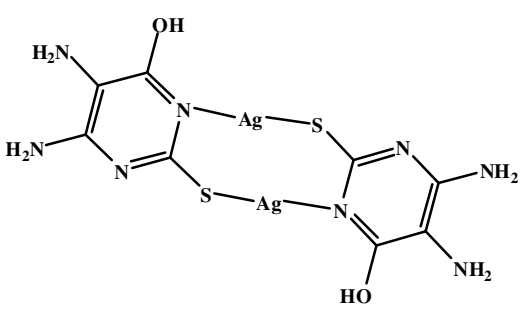

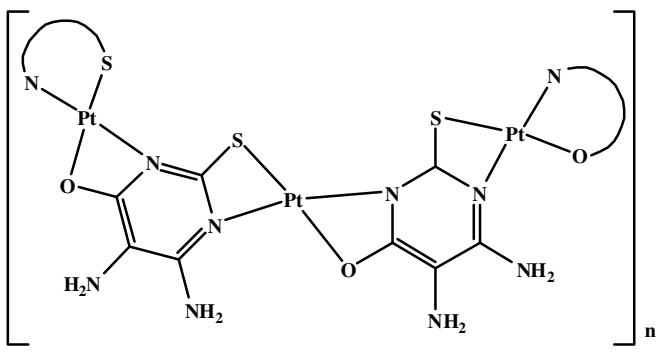

Fig. 29. Structure of Hdahmp Schiff base metal complexes 
lung cancer cell line (A549) breast cancer cell line (MDAMB-231) and cervical cancer cell line (Hela). The metal complexes exhibit significant effect on the proliferation of A-549 cancer cell line [43].

Benzaimidazole moiety containing Schiff base ligands were prepared and formed copper complexes. These metal complexes were evaluated against various human breast cancer cell line (MCF-7) cell line and human colorectal cancer cell line (COLO205). The cytotoxic and antiproliferative activity of metal complexes against MCF-7 line show $\mathrm{IC}_{50}$ value $=16.9$ $\pm 1.5 \mathrm{mmol}^{-1}$ and for colorectal cancer cell line the $\mathrm{IC}_{50}$ value $=16.5 \pm 3.4 \mu_{\mathrm{mol}^{-1}}$ which is stronger than the ligand and can have the potential to act as anticancer drug [44].

Gaber et al. [45] synthesized Schiff base ligand and its $\mathrm{Ni}(\mathrm{II}), \mathrm{Pt}(\mathrm{II})$ and $\mathrm{Pd}(\mathrm{II})$ complexes by the condensation of 2-hydroxy-1-napthaldehyde and 3-amino-1,2,4-triazole. The antitumour activity of metal complexes were investigated for liver carcinoma (HepG-2) cell line. The results showed that ligand has greater cytotoxic activity than metal complexes.

Chiral Schiff base metal complexes of copper and nickel were synthesized from R/S-2-[1-hydroxymethylpropylimino)methyl]-5-methoxyphenol and its derivatives. The in vitro cytotoxicity activity of the complexes were investigated for various human lung cervical cell line (Hela), human lung adenocarcinoma (A549) and human breast cancer cell line (MCF-7) by the MTT assay. The results showed that copper and nickel complexes exhibited good cytotoxic activity [46].

Diacetone based copper(II) complexes were synthesized using 1-naphthyl N,N [bis(2-pyridyl)methyl]amines. The cancerous cell line such as (Hela, MCF-7, Bel-7404 and HepG2 ) were tested for in vitro cytotoxicity of the metal complexes. All the metal complexes exhibit high potential cytotoxic effect with less $\mathrm{IC}_{50}$ value. The studies showed that the antitumour activity of metal complexes were stronger [47].

Jiao et al. [48] also reported a new dinuclear copper(II) complex by condensing $2,2^{\prime}$-diamino-4, $4^{\prime}$-bithiazole with $\mathrm{N}$ [3-dimethylamino)propyl]-N'-(2-carboxylatophenyl)oxamide. The copper(II) complexes were tested for in vitro anticancer activities. The copper complexes were more active against the cancerous cell line and act as a better dose dependent cytotoxic drug.

Nickel salicylidene Schiff base metal complex were synthesized and characterized by Li et al. [49]. The coordination of nickel(II) ion by ONNO donor in a tetradendate manner have been confirmed by single crystal X-ray structure. The complex were examined for the in vitro cytotoxicity on cancerous cell lines such as human coloncarcinoma cell line (HCT-116), human lung carcinoma line (A549) and colonic cancer cell line (CaCo2). The results showed that all the nickel complexes exhibit high potential cytotoxic activity.

Jaividhya et al. [50] synthesized a series of mixed ligand copper(II) complexes of anthracene based Schiff base ligand with 1,10-phenanthroline. The in vitro cytotoxicity of the ligand were tested against human breast cancer cell line MCF-7. The studies show that the $\mathrm{IC}_{50}$ value is less than that of cisplatin for the same cell line and can act as better cytotoxic drug.

Rajarajeswari et al. [51] synthesized a new series of $\mathrm{Cu}$ (II) complex of tridendate ligand with two nitrogen donor like 2-(2-
(1H-benzimidazole-2-yl)ethylimino methyl)phenol with 1,10phenanthroline and also chloride complex of tridendate ligands. The copper complexes were investigated with human breast cancer cell line (HBL-100) by MTT assay. It was found that copper(II) complex with two nitrogen donor atom exhibited more potential to act as efficient cytotoxic drug than the chloride complex [51].

\section{Conclusion}

Latest advances in bioinorganic chemistry gives considerable possibilities for the utilization of metal complexes inside the improvement of anticancer capsules. The researchers attempted to discover the complicated, mechanism of action and showed that rather than inducing apoptosis the compound arrest cellular cycle development. The destiny development of medicinal inorganic chemistry requires an understanding of the physiological processing of metal complexes to offer a rational basis for the layout of recent metal based tablets.

\section{CONFLICT OF INTEREST}

The authors declare that there is no conflict of interests regarding the publication of this article.

\section{REFERENCES}

1. H. Ali and J.E. van Lier, Chem. Rev., 99, 2379 (1999); https://doi.org/10.1021/cr980439y.

2. A.Y. Louie and T.J. Meade, Chem. Rev., 99, 2711 (1999); https://doi.org/10.1021/cr9804285.

3. W.A. Volkert and T.J. Hoffman, Chem. Rev., 99, 2269 (1999); https://doi.org/10.1021/cr9804386.

4. H. Grunicke, W. Doppler and W. Helliger, Arch. Geschwulstforsch., 56, 193 (1986).

5. N.V. Krakhmal, M.V. Zavyalova, E.V. Denisov, S.V. Vtorushin and V.M. Perelmuter, Acta Naturae., 7, 17 (2015).

6. E. Espinosa, P. Zamora, J. Feliu and M. González Barón, Cancer Treat. Rev., 29, 515 (2003); https://doi.org/10.1016/S0305-7372(03)00116-6.

7. K. Hariprasath, B. Deepthi, I. Sudheer Babu, P. Venkatesh, S. Sharfudeen and V. Soumya, J. Chem. Pharm. Res., 2, 496 (2010).

8. S. Rafique, M. Idrees, A. Nasim, H. Akbar and A. Athar, Biotechnol. Mol. Biol. Rev., 5, 38 (2010).

9. M. Frezza, S. Hindo, D. Chen, A. Davenport, S. Schmitt, D. Tomco and Q. Ping Dou, Curr. Pharm. Des., 16, 1813 (2010); https://doi.org/10.2174/138161210791209009.

10. K. Andiappan, A. Sanmugam, E. Deivanayagam, K. Karuppasamy, H.S. Kim and D. Vikraman, Sci. Rep., 8, 3054 (2018); https://doi.org/10.1038/s41598-018-21366-1.

11. M.-J. Niu, Z. Li, G.-L. Chang, X.-J. Kong, M. Hong and Q.-F. Zhang, PLoS One, 10, e0130922 (2015); https://doi.org/10.1371/journal.pone.0130922.

12. R.A. Sheikh, M.Y. Wani, S. Shreaz and A.A. Hashmi, Arab. J. Chem., 9, 743 (2016); https://doi.org/10.1016/j.arabjc.2011.08.003.

13. Z. Shokohi-pour, H. Chiniforoshan, A.A. Momtazi-borojeni and B. Notash, J. Photochem. Photobiol., 162, 34 (2016); https://doi.org/10.1016/j.jphotobiol.2016.06.022.

14. M. Hajrezaie, M.J. Paydar, S.Z. Moghadamtousi, P. Hassandarvish, N.S. Gwaram, M. Zahedifard, E. Rouhollahi, H. Karimian, C.Y. Looi, H.M. Ali, N.A. Majid and M.A. Abdulla, Sci. World J., 2014, 540463 (2014); https://doi.org/10.1155/2014/540463.

15. Y.J. Xiao, Q.C. Diao, Y.H. Liang and K. Zeng, Braz. J. Med. Biol. Res., 50, e6390 (2017); https://doi.org/10.1590/1414-431X20176390.

16. K.S. Kumar and C. Priya Varma, J. Pharm. Sci. Res., 9, 1317 (2017).

17. M. Hong, H. Geng, M. Niu, F. Wang, D. Li, J. Liu and H. Yin, Eur. J. Med. Chem., 86, 550 (2014); https://doi.org/10.1016/j.ejmech.2014.08.070. 
18. H.M. Faidallah, A.A. Saqer, K.A. Alamry, K.A. Khan, M.A.M. Zayed and S.A. Khan, Asian J. Chem., 26, 8139 (2014); https://doi.org/10.14233/ajchem.2014.17616.

19. A.A. Radwan, T. Aboul-Fadl, A. Al-Dhfyan and W.M. Abdel-Mageeda, Asian J. Chem., 26, 8145 (2014); https://doi.org/10.14233/ajchem.2014.17636.

20. A.S. El-Tabl and M.S. Ahmed Shahin, Int. J. Adv. Chem., 4, 01 (2018). https://doi.org/10.5121/ijac.2018.4101.

21. A.S. Alturiqi, A.-N.M. A. Alaghaz, R.A. Ammar and M.E. Zayed, $J$. Chem., 2018, 5816906 (2018); https://doi.org/10.1155/2018/5816906.

22. M M. Shoaib, G. Rahman, S.W. Ali Shah and M.N. Umar, Bangladesh J. Pharmacol., 10, 332 (2015); https://doi.org/10.3329/bjp.v10i2.22471.

23. K. Sathish Kumar, V.K. Chityala, N.J.P. Subhashini, Y. Prashanthi and Shivaraj, ISRN Inorg. Chem., 2013, 562082 (2013); https://doi.org/10.1155/2013/562082.

24. R. Gomathi, A. Ramu and A. Murugan, Bioinorg. Chem. Appl., 2014, 215392 (2014); https://doi.org/10.1155/2014/215392.

25. V.K. Chityala, K. Sathish Kumar, R. Macha, P. Tigulla and Shivaraj Bioinorg. Chem. Appl., 2014, 691260 (2014); https://doi.org/10.1155/2014/691260.

26. Y. Peng, H. Zhong, Z.-F. Chen, Y.-C. Liu, G.-H. Zhang, Q.-P. Qin and H. Liang, Chem. Pharm. Bull. (Tokyo), 62, 221 (2014); https://doi.org/10.1248/cpb.c13-00256.

27. W. Hernández, J. Paz, F. Carrasco, A. Vaisberg, E. Spodine, J. Manzur, L. Hennig, J. Sieler, S. Blaurock and L. Beyer Bioinorg. Chem. Appl., 2013, 524701 (2013); $10.1155 / 2013 / 524701$

28. K. Starèeviæ, M. Kralj, K. Ester, I. Sabol, M. Grce, K. Paveliæ and G. Karminski-Zamola, Bioorg. Med. Chem., 15, 4419 (2007); https://doi.org/10.1016/j.bmc.2007.04.032.

29. Z.C. Liu , B.D. Wang, Z.Y. Yang, Y. Li, D.D. Qin and T.R. Li, Eur. J. Med. Chem., 44, 4477 (2009); https://doi.org/10.1016/j.ejmech.2009.06.009.

30. M.A. Malik, O.A. Dar, P. Gull, M.Y. Wani and A.A. Hashmi, Med. Chem. Commun., 9, 409 (2018); https://doi.org/10.1039/C7MD00526A.

31. M.M. Abd-Elzaher, A.A. Labib, H.A. Mousa, S.A. Moustafa, M.M. Ali and A.A. El-Rashedy, Beni-Seuf Univ. J. Basic Appl. Sci., 5, 85 (2016); https://doi.org/10.1016/j.bjbas.2016.01.001.

32. R.M. Shafeeulla, G. Krishnamurthy, H.S. Bhojynaik, H.P. Shivarudrappa and Y. Shiralgi, Beni-Seuf Univ. J. Basic Appl. Sci., 6, 332 (2017); https://doi.org/10.1016/j.bjbas.2017.06.001

33. Y. Prashanthi, K. Kiranmai, Ira, K. Sathishkumar, V.K. Chityala and Shivarj, Bioinorg. Chem. Appl., 2012, 948534 (2012); https://doi.org/10.1155/2012/948534.

34. Ö. Sahin, Ü.Ö. Özdemir, N. Seferoglu, Z.K. Genc, K. Kaya, B. Aydiner, S. Tekin and Z. Seferoglu, J. Photochem. Photobiol., 178, 428 (2018); https://doi.org/10.1016/j.jphotobiol.2017.11.030.

35. S. Jean, K. Cormier, A.E. Patterson, C.M. Vogels, G.A. Robichaud, A. Decken, S. Turcotte and S.A. Westcott, Can. J. Chem., 93, 1140 (2015); https://doi.org/10.1139/cjc-2015-0157.
36. R. Manikandan, P. Viswanathamurthi, K. Velmurugan, R. Nandhakumar, T. Hashimoto and A. Endo, J. Photochem. Photobiol., 130, 205 (2014); https://doi.org/10.1016/j.jphotobiol.2013.11.008.

37. S.A. Elsayed, B.J. Jean-Claude, I.S. Butler and S.I. Mostafa, J. Mol. Struct., 1028, 208 (2012); https://doi.org/10.1016/j.molstruc.2012.05.073.

38. F.A. El-Morsy, B.J. Jean-Claude, I.S. Butler, S.A. El-Sayed and S.I. Mostafa, Inorg. Chim. Acta, 423, 144 (2014); https://doi.org/10.1016/j.ica.2014.07.031.

39. A.A. Alie El-Deen, A. El-Monem, E. El-Askalany, R. Halaoui, B.J. Jean-Claude, I.S. Butler and S.I. Mostafa, J. Mol. Struct., 1036, 161 (2013); https://doi.org/10.1016/j.molstruc.2012.09.045.

40. C.S. Allardyce and P.J. Dyson, Dalton Trans., 45, 3201 (2016); https://doi.org/10.1039/C5DT03919C.

41. S. Shen, H. Chen, T.F. Zhu, X.Q. Ma, J. Xu, W.J. Zhu, R.H. Chen, J. Xie,T.L. Ma, L. Jia, Y. Wang, and C.Y. Peng, Oncol. Lett., 13, 3169 (2017); https://doi.org/10.3892/ol.2017.5857.

42. W.-J. Lian, X.-T. Wang, C.-Z. Xie, H. Tian, X.-Q. Song, H.-T. Pan, X. Qiao and J.-Y. Xu, Dalton Trans., 45, 9073 (2016); https://doi.org/10.1039/C6DT00461J.

43. A. Paul, S. Anbu, G. Sharma, M.L. Kuznetsov, B. Koch, M.F.C. Guedes da Silva and A.J.L. Pombeiro, Dalton Trans., 44, 19983 (2015); https://doi.org/10.1039/C5DT02880A.

44. W.-J. Song, J.-P. Cheng, D.-H. Jiang, L.Guo, M.-F. Cai, ,H.-B. Yang and Q.-Y. Lin, Spectrochim. Acta Part A: Mol Biomol. Spectrosc., 121, 70 (2014); https://doi.org/10.1016/j.saa.2013.09.142.

45. M. Gaber, H.A. El-Ghamry and S.K. Fathalla, Spectrochim. Acta A Mol. Biomol. Spectrosc., 139, 396 (2015); https://doi.org/10.1016/j.saa.2014.12.057.

46. Z. Li, H. Yan, G. Chang, M. Hong, J. Dou and M. Niu, Photochem. Photobiol. B., 163, 403 (2016); https://doi.org/10.1016/j.jphotobiol.2016.09.005.

47. X.Q. Zhou, Q. Sun, L. Jiang, S.T. Li , W. Gu , J.L. Tian, X. Liu and S.P. Yan, Dalton Trans., 44, 9516 (2015); https://doi.org/10.1039/c5dt00931f.

48. J. Jiao, M. Jiang, Y.T. Li, ZY. Wu and C.W. Yan, J. Biochem. Mol. Toxicol., 28, 47 (2014); https://doi.org/10.1002/jbt.21535.

49. P. Li, M. Niu, M. Hong, S. Cheng and J.J. Dou, Inorg. Biochem., 137, 101 (2014); https://doi.org/10.1016/j.jinorgbio.2014.04.005.

50. P. Jaividhya, M. Ganeshpandian, R. Dhivya, MA. Akbarsha and M. Palaniandavar, Dalton Trans., 44, 11997 (2015); https://doi.org/10.1039/c5dt00899a.

51. C. Rajarajeswari, M. Ganeshpandian, M. Palaniandavar, A. Riyasdeen and M.A. Akbarsha, J. Inorg. Biochem., 140, 255 (2014); https://doi.org/10.1016/j.jinorgbio.2014.07.016. 